\title{
https://doi.org/10.30853/filnauki.2018-6-2.1
}

\section{Алиева Айнура Али кызы}

\section{О ПРЕПОДАВАНИИ КОМЕДИЙ М. Ф. АХУНДОВА СТУДЕНТАМ РУССКОГО СЕКТОРА}

АЗЕРБАЙДЖАНСКИХ ВУЗОВ

В статье выявлены некоторые способы восприятия комедий М. Ф. Ахундова студентами русского сектора филологических факультетов вузов Азербайджана. Драматургическое наследие этого классика значимо по своей идейной проблематике. Перед анализом комедий Ахундова в статье даются методические рекомендации для ознакомления студентов с политической обстановкой середины XIX века в России и Азербайджане. Отмечается, что М. Ф. Ахундова связывали тесные отношения с деятелями русской литературы. Отталкиваясь от позиций современных азербайджанских литературоведов, автор выявляет ключевые аспекты комедии Ахундова.

Адрес статьи: www.gramota.net/materials/2/2018/6-2/1.html

\section{Источник}

Филологические науки. Вопросы теории и практики

Тамбов: Грамота, 2018. № 6(84). Ч. 2. C. 221-224. ISSN 1997-2911.

Адрес журнала: www.gramota.net/editions/2.html

Содержание данного номера журнала: www.gramota.net/materials/2/2018/6-2/

\section{(С) Издательство "Грамота"}

Информация о возможности публикации статей в журнале размещена на Интернет сайте издательства: www.gramota.net Вопросы, связанные с публикациями научных материалов, редакция просит направлять на адрес: phil@gramota.net 


\section{ЛИТЕРАТУРОВЕДЕНИЕ}

УДК 82

https://doi.org/10.30853/filnauki.2018-6-2.1

В статье выявлены некоторые способы восприятия комедий М. Ф. Ахундова студентами русского сектора филологических факультетов вузов Азербайджана. Драматургическое наследие этого классика значимо по своей идейной проблематике. Перед анализом комедий Ахундова в статье даются методические рекомендации для ознакомления студентов с политической обстановкой середины ХІХ века в России и Азербайджане. Отмечается, что М. Ф. Ахундова связывали тесные отношения с деятелями русской литературы. Отталкиваясь от позиций современных азербайджанских литературоведов, автор выявляет ключевые аспекты комедии Ахундова.

Ключевые слова и фразы: драматургия; комедия; М. Ф. Ахундов; феодально-патриархальный строй; религиозный фанатизм; жанр; просвещение.

\section{Алиева Айнура Али кызы}

Институт проблем образования Министерства образования Азербайджанской Республики, г. Баку arzu.mamedova.77@mail.ru

\section{О ПРЕПОДАВАНИИ КОМЕДИЙ М. Ф. АХУНДОВА СТУДЕНТАМ РУССКОГО СЕКТОРА АЗЕРБАЙДЖАНСКИХ ВУЗОВ}

Основоположник новой азербайджанской реалистической литературы, выдающийся просветитель и демократ Мирза Фатали Ахундов (1812-1878) жил и творил в тех условиях, когда происходили радикальные изменения в общественно-политической жизни страны. Они были, прежде всего, связаны с позитивным для тех лет фактом присоединения Азербайджана к России в XIX столетии. Это важное политическое событие в дальнейшем сыграло огромную роль в развитии русско-азербайджанских литературных и культурных взаимосвязей.

Перед ознакомлением с драматургической деятельностью Ахундова студентам русского сектора, на наш взгляд, необходимо глубже ознакомиться с исторической обстановкой отдалённого от нас времени, знать, что Азербайджан был тогда отсталой страной, раздробленной многочисленными феодальными ханствами.

После вхождения Азербайджана в состав Российской империи начался процесс сближения передовой азербайджанской мысли с прогрессивной русской идеологией. Литература как одна из форм общественного сознания также движется вперёд, хотя и с очень большим трудом.

Анализировать идейное содержание шести комедий Ахундова, упуская из виду их связь с русской классической драматургией XIX века, недопустимо, так как у студентов может сложиться неверное впечатление об изоляции двух культур в целом. Между тем связь азербайджанской реалистической литературы и драматургии Ахундова в первую очередь не подлежит сомнению, о чем писали азербайджанские литературоведы [3; 7; 8; 11]. Не повторяя сказанного ими, в настоящей статье отметим, что русская литература «золотого века» развивалась и достигла своего расцвета под знаменами критического реализма. По своей проблематике она была социальной, а по идейной направленности - демократической. Это было обусловлено определёнными историческими условиями, экономической и политической отсталостью, голодом, нуждой, недовольством царской политикой, ростом национального самосознания и мировоззрения народных масс. Отсюда тесная связь русской реалистической литературы с народно-освободительным движением, отражением в ней борьбы классов в русском обществе. Правда жизни, отображение типичных ее сторон, активное вторжение в реальную действительность, отрицание и обличение враждебного народу правящего режима, утверждение нового, передового, воплощённого в положительных образах, показ лучших качеств русскою народа - эти черты характеризовали русскую классическую литературу ХІХ века. Определённая часть из них, безусловно, отразилась и в передовой азербайджанской литературе указанного периода.

В азербайджанской литературе было несколько иное положение, чем в русской. В ней к интересующему нас периоду имелись лишь зачатки реализма, отдельные элементы реалистического отображения действительности, близости к народному языку и к формам национальной поэзии, характерные для произведений Молла Панаха Вагифа (конец XVIII века) и Касум бека Закира (начало XIX века). Свойственные для Азербайджана того времени исторические условия, низкий экономический и культурный уровень не способствовали зарождению реализма в отображении жизни. Схоластический характер литературы не сдавал свои 
позиции. Верные представления об условиях становления и развития просветительских идей в России и Азербайджане помогут студентам чётче и яснее осознать общую картину развития реализма двух стран, точнее и объективнее оценить роль национальной литературы в целом и драматургии Ахундова в частности.

Прямое (или косвенное) знакомство Ахундова с русскими литераторами своего времени помогало ему пропагандировать идею дружбы между двумя народами, содействовало сближению азербайджанской литературы с русской. Ахундов опирался на реалистические традиции русской литературы и потому обобщение им социальных явлений в конкретных образах, отстаивание в национальной литературе метода критического реализма сближали его комедии с образцами русской реалистической драматургии.

Обращение Ахундова к теории и практике русской реалистической литературы естественно не принижает его самобытности; он следовал им не слепо, не подражая, а осмысливая и перерабатывая в соответствии с национальным менталитетом. Так, можно поставить перед студентами вопрос о том, что в его комедиях нет прямого заимствования. Ахундову-драматургу были по духу и нраву идеи русских реалистов, он был демократом, любил свой народ, ненавидел угнетение и несправедливость в любых формах их проявления.

Сказанное свидетельствует об умении Ахундова понять историческую обстановку и основные требования народа, прозорливо видеть его будущее. В наши дни, когда художественная литература и история как научная дисциплина «переписываются» набело, преподаватель вуза обязан предостеречь студентов от возможных ошибок в излишней либерализации мировоззренческих установок Ахундова.

В этом отношении преподаватель-словесник в целях правильного восприятия идейного содержания комедий Ахундова обязан восполнить пробел студентов русского сектора. Для этого он, с одной стороны, должен пресечь возможные попытки сбора научной информации через Интернет, а с другой - ставить заслон перед слепым восприятием устаревших положений работ азербайджанских литературоведов прошлых лет.

Так, автор изданной в Москве монографии «Ахундов», профессор М. Г. Рафили [7], еще в 1930-х годах опубликовал в журнале «Литературный Азербайджан» серию статей о шести комедиях Ахундова [8], где отмечал «почти полное взаимопроникновение идей азербайджанского классика в суть русской драматургии» [Там же, с. 57]. Всестороннего проникновения идей одной национальной литературы в другую, более развитую к тому времени в политико-идеологическом аспекте, не было. На наш взгляд, это литературная натяжка. Мягче высказывался по этому поводу известный исследователь русско-азербайджанских литературных взаимоотношений Ш. К. Курбанов [6], осторожно заметивший: «Можно отметить наличие литературных связей, вернее сказать, тяготение представителей передовой азербайджанской культуры к культуре русского народа, которое в 50-60-х годах переходит во взаимные связи» [5, с. 112].

Другой пример. Исследовательница М. М. Алиева в одной из своих статей писала: «В азербайджанской литературе к середине XIX века уже наблюдается явное оживление, страстное стремление к более глубокому изучению и познанию живой действительности, присутствует критика старого быта, обычаев, предрассудков. С одной стороны, она развивается на национальных традициях азербайджанского народа, с другой близко соприкасается с литературой великого русского народа, впитывает в себя лучшие её черты» [1, с. 70]. Нетрудно заметить, что имеющиеся в цитате высокопарные эпитеты, доводящие искомый признак до максимализма, отнюдь не разъясняют поставленный автором вопрос о драматургическом мастерстве Ахундова.

Национальное чутье азербайджанского драматурга, дополненное основательными знаниями в области достижений русской и мировой культуры, привело его к отрицанию идеи «чистого искусства» в литературе. Он не приравнивал литературу к средствам развлечения (что доказывают его комедии). По Ахундову, комедия своей сатирической заострённостью должна правдиво отражать особенности жизни народа, обличать пороки существующего строя. Она должна своим юмором, то есть осмысленным смехом способствовать развитию общественного сознания. Он считал, что драматургические произведения способны воспитать молодое поколение, пропагандировать достойный образ жизни, выявлять новое, прогрессивное, бороться за него, воплощать эти новации в положительных образах. Стремясь как можно быстрее ознакомить русских и русскоязычных читателей со своими комедиями, он первым сам перевел их на русский язык [2, с. 9].

В борьбе за реалистическую литературу Ахундов требовал пересмотра вопроса о литературных жанрах, ибо считал, что с изменением исторических условий изменяются не только стиль, содержание, идея, форма, но и сам жанр. Жизнь требует от писателя, утверждал Ахундов, писать правду и только правду; требует, чтобы литература стала обличительной, отвечала требованиям современности.

Если студенты филологических факультетов вузов республики хотя бы вкратце знакомы с творчеством видных русских и европейских драматургов, то им легче будет понять, почему Ахундов считал драму самой актуальной жанровой формой художественного произведения. На этой принципиальной позиции драматурга в русскоязычной аудитории следует остановиться особо. Как отмечает профессор Р. Г. Кулиева: «Жанр драмы для просветителей был одним из самых важных в том плане, что был он доступен при постановке на театральных сценах самым широким массам зрителей, даже для тех, кто не имел возможности читать. Сцена тем самым становилась своеобразной трибуной для проведения идей писателей. В просветительской драме главный акцент делался на разрешимости важнейших вопросов - политических, социальных, нравственных - путём Просвещения» [4, с. 47].

В самом деле, темы и идеи комедий Ахундова напрямую были связаны с идейно-тематическими поисками европейского просвещения. В них в центре внимания - обличение косности и мракобесия. Выявить и показать социальные пороки можно было именно в жанре комедии, реалистическом и глубоко самобытном, с национальными содержанием и формой. 
Студентам следует разъяснить, что театральные подмостки Санкт-Петербурга и Москвы, а также уровень европейского просвещения в середине XIX века отличался от аналогичных видов искусств в Азербайджане этого периода. Восточные нравы настолько подавляли личность, что художникам сложно было проявлять инициативу. Просветители во все времена искренне верили в магическую силу драматургического искусства. Элементы театра издавна распространены на Востоке. Ахундов понимал, что для развития драматического искусства «необходимы политические перемены, борьба с господствующим в стране фанатизмом» [2, с. 7]. Время требовало создания новой литературной формы, способной отвечать насущным задачам общественной жизни.

В подтверждение этих теоретических мыслей Ахундов и пишет шесть комедий. Комедия для него оказалась наиболее реальным и доступным жанром, при помощи которого легко можно изобразить и высмеять человеческие пороки и недостатки современников, разрешить ряд социальных задач, прежде всего искоренить и уничтожить человеческие пороки, дурные привычки. Ирония и смех стали главным действенным оружием драматурга.

Видя актуальность выбранного им жанра, Ахундов выступал в комедиях как художник, просветитель, демократ, глубокий патриот. Материалом для комедий служила сама жизнь. Он не мог не видеть жестокого угнетения народа, его невежества; понимал, что государство опирается на реакционное духовенство, способное держать народ в темноте, в узде религиозного фанатизма, социального гнета, видел преклонение господствующих слоев, купцов перед властью денег, тяжёлую жизнь восточной женщины, произвол распоясавшихся чиновников. Поэтому главной темой его комедий явилась критика общественных порядков, народ, его интересы и судьба. В своих комедиях Ахундов рисует типические реалистические картины тогдашней жизни, раскрывает ее основные конфликты, пороки, быт, нравы и традиции.

Ахундов ставит актуальные вопросы, волнующие передовых людей того времени: вопрос о социальном неравенстве, критика духовенства, недостатки существующего строя, неприспособленность представителей господствующей власти управлять народом, столкновение классов, мировоззрений, положение женщины в семье и обществе.

Отрицательные образы комедий Ахундова - лицемерные чиновники, на все готовые ради личной наживы. В комедии «Молла Ибрагим Халил алхимик, обладатель философского камня» жители города Нуха - нухинцы - для обхода цензуры показаны достопочтенными гражданами, но взыскательным зрителям понятно, что это жадные ханжи, преграждающие дорогу прогрессу. В названной комедии негативное присуще всем представителям привилегированных слоев тогдашнего общества: помещикам (Сафарбек), духовенству (Молла Салман), купечеству (Мешади Джаббар), «интеллигенции» (Ага Заман), ремесленникам (Гаджи Керим).

В комедии «Приключения визиря Ленкоранского ханства» это Хан и Визирь, всячески препятствующие справедливости, грабящие и угнетающие народ. В комедии «Приключения скряги, или Гаджи-Кара» это и сам Гаджи-Кара, купец, подчинивший свою жизнь стяжательству, и Гейдар-бек, дворянин-пустозвон, мечтающий о подвигах. В комедии «Правозаступники в городе Тебризе» это адвокат Ага Мардан и его подручные, алчные, бесчестные, низкие люди, решающие судьбы сотен беззащитных людей.

Ахундов раскрывает типические черты диких нравов представителей господствующих слоев общества, символизирующих существующие в стране порядки. В его комедиях такого рода герои терпят крах. Не приспособленные к трудностям жизни, лишенные каких-либо светлых идеалов, они, сталкиваясь с трудностями, гибнут.

Ахундов даёт понять, что отрицательные типажи в его комедиях - это вчерашний день, возврата к которому нет.

По Ахундову, строй, основанный на неравенстве и угнетении, непрочен. В то же время через все комедии лейтмотивом проходит сочувствие угнетенному народу. Народ в его комедиях противопоставляется порочному, паразитическому господствующему обществу. В комедиях Ахундова герои из народа, как правило, трудолюбивы, добры, честны, гуманны, любят родину, полны национального своеобразия. «Труд вот эликсир жизни!» - восклицает положительный герой Гаджи Нури. Труд созидает, делает жизнь человека осмысленной, полезной. Ахундов поет гимн честному, разумному, созидательному труду устами Гаджи Нури, бросающему вызов тунеядцам.

Однако не зря же в народе говорят «не зарывать талант в землю». «Эликсир жизни», к сожалению, становится для Гаджи Нури его же могилой. Талант не приносит реальной пользы и счастья народу. В трактовке этого отнюдь не однозначного образа имеются некоторые разночтения в азербайджанском литературоведении, которые преподавателю следует разъяснить студентам.

Так, Дж. Джафаров в монографии «Драматургия М. Ф. Ахундова» утверждает, что «эту идею» комедиограф будет развивать и в последующих произведениях, в особенности философско-политических. Справедливо подчёркивая, что «здесь идея “эликсира-таланта” пока не раскрыта, и художественными красками выражена лишь в форме тезиса, в силу чего Гаджи Нури получился несколько схематичным и неполнокровным» [3, с. 49], Дж. Джафаров, себе противореча, заявляет, что эликсир - «это также свобода личности, наконец, любовь к родной стране и своему народу» [Там же, с. 60].

Философский постулат «свободы личности» в наши дни ко многому обязывает. Учитывая многочисленные публикации в современных средствах массовой информации на тему «свободы личности» у студентов может сложиться неверное толкование идейного замысла Ахундова. Правильное же восприятие тезиса зависит от объединения понятий «свободы личной» и «общественной». Кроме того, следует объяснить, что свобода - это не вседозволенность. Свобода распоясавшихся чиновников, по Ахундову, - бич азербайджанского общества. На наш взгляд, Дж. Джафаров неправ: такое понимание свободы личности к Гаджи Нури прямого отношения не имеет. 
В комедии «Медведь, победитель разбойника» Ахундов показал своеобразные и лучшие черты представителей азербайджанского народа: природный ум, рассудительность, тонкий юмор, храбрость, искренность. Но, следуя правде жизни, Ахундов показывает, что крестьяне еще слишком забиты, невежественны, не подготовлены к тому, чтобы отстоять свою правоту; они угнетены и эксплуатируемы. Ахундов делает вывод, что главная причина такого тяжелого положения народа, его невежества в общественных условиях, враждебных человеку, сковывающих его, обрекающих на творческий застой, - именно в социальном строе, который не соответствует интересам народа. Жизнь сама выставляет требование - разоблачать это несоответствие, порожденное существующими порядками. Выход из этого положения, по мнению Ахундова, заключается в пробуждении сознательности народа. Только пробудившийся народ может встать на защиту своих прав, ибо только в народе - разумное начало.

Будучи оптимистом, Ахундов верил в народ. Именно поэтому лейтмотивом его комедий является борьба за светлое будущее. По Ахундову, жизнь постоянно в движении, ею управляет прогресс. Новые ростки, стремящиеся к свободе, восставшие против ханжества, встречают сопротивление со стороны представителей господствующего строя. Именно поэтому драматург зачастую облагораживает своих положительных персонажей, несколько поэтизирует их.

В доказательство следует заострить внимание студентов на природе таких образов из комедии «Мусье Жордан, ботаник, и дервиш Мастали шах», как Шахбаз-бек, яркий представитель передовой дворянской молодежи, Гаджи Нури, честный и умный юноша, стремящийся к науке. Порывы к знаниям, широта мысли и порядочность делают этих персонажей глубоко обаятельными. Подобных героев достаточно много в комедиях Ахундова.

Список источников

1. Алиева М. М. Русская реалистическая драматургия и драматургия Мирза Фатали Ахундова // Учёные записки Азербайджанского государственного университета. Серия языка и литературы. 1966. № 5. С. 69-78.

2. Ахундов М. Ф. Комедии. Баку: Академия наук Азербайджанской ССР, 1956. 210 с.

3. Джафаров Дж. Г. Драматургия М. Ф. Ахундова. Баку: Издательство детской и юношеской литературы, 1950.187 с.

4. Кулиева Р. Г. Просветительские идеи в драматургии М. Ф. Ахундова // Восток - Запад: сборник научно-исследовательских работ сотрудников научно-исследовательской лаборатории «Тюрко-славянские связи» с 2005 по 2015 год: в 2-х т. Баку: Мутарджим, 2016. Т. 2. С. 45-52.

5. Курбанов Ш. К. Азербайджанско-русские литературные связи. Баку: Академия наук Азербайджанской ССР, 1964. 241 с.

6. Курбанов Ш. К. Этапы развития азербайджанско-русских литературных связей XIX века. М.: Наука, 1976. 301 с.

7. Рафили М. Г. Ахундов. М.: Молодая гвардия, 1959. 132 с.

8. Рафили М. Г. О комедиях М. Ф. Ахундова // Литературный Азербайджан. 1938. № 7. С. 54-61.

9. Садыхов М. 3. М. Ф. Ахундов и русская литература. Баку: Язычи, 1986. 235 с.

10. Сеидзаде А. А. О переводах произведений М. Ф. Ахундова на русский язык // Труды Азербайджанского государственного университета им. С. М. Кирова. Серия филологическая. 1940. Т. 2. Вып. 1. С. 11-19.

11. Соловьев В. М. Ф. Ахундов и русская культура // Известия Азербайджанского филиала Академии наук СССР. 1936. № 6. C. 11-19.

\title{
ON TEACHING M. F. AKHUNDOV'S COMEDIES TO THE STUDENTS OF THE RUSSIAN SECTOR OF AZERBAIJANI HIGHER EDUCATION ESTABLISHMENTS
}

\author{
Alieva Ainura Ali kyzy \\ Institute of Education of the Ministry of Education of the Azerbaijani Republic, Baku \\ arzu.mamedova.77@mail.ru
}

The article identifies the ways of perceiving M. F. Akhundov's comedies by philological students of the Russian sector of Azerbaijani higher education establishments. The writer's dramaturgic heritage is meaningful in its ideological problematics. Before analyzing M. F. Akhundov's comedies the paper proposes methodical recommendations to acquaint the students with the political situation that had developed in Russia and Azerbaijan by the middle of the XIX century. It is shown that M. F. Akhundov was in close relations with Russian literary figures. Relying on the conceptions of modern Azerbaijani literary critics the author identifies the key aspects of M. F. Akhundov's comedies.

Key words and phrases: dramaturgy; comedy; M. F. Akhundov; feudal and patriarchal regime; religious fanaticism; genre; education. 